\title{
NEW CONTRIBUTION IN THE STUDY OF THE PONTIAN FLORA FROM BATOȚI (MEHEDINȚI COUNTY)
}

\author{
FLORINA DIACONU ${ }^{1}$
}

\begin{abstract}
In Early Pontian deposits from Batoți (Mehedinți county) has been described a macroflora formed, until now, of 35 taxa, many other being in course of determination. By this paper the floristic epitome is filled with other 10 taxa: Pinus sp. binae, Magnolia sp. aff. M. acuminata Linné, Sassafras subtriloba (Konno) Tanai et Onoe, Ostrya sp. aff. O. virginiana (Miller) C. Koch, Castanea gigas (Goepp.) lljinsk., Quercus cf. meuhlenbergii Engelmann, Juglans acuminata Al. Braun, Acer tricuspidatum Bronn, A. cf. campestre L. and Berchemia multinervis (Al. Br.) Heer. The stage of knowledge of the Pontian flora from Batoți contains 45 taxa. Trough the listed taxa the degree of confidence of the paleoecologycal and paleophytocenotical rendering grows.
\end{abstract}

Key words: Early Pontian, macroflora, Batoți exposure, SW Romania

\section{INTRODUCTION}

The study of the fossil flora from Batoți has represented the main concern starting the year 2000. All these papers describe the fossil flora and vegetation from the left bank of the Danube, where it appears a succession of deposits, mainly clay, with a rich content in fossil vegetal remains.

The palinological (Petrescu et al., 2002) and the macrofloristic researches (Țicleanu et al., 2002; Diaconu, 2002, Diaconu et al., 2003; Diaconu 2004, in press) recently done in the fossiliferous site from Batotii have shown that this represents a large variety of species. The quantity of the determined fossil material, the perfection of the preservation, the variety and sometimes the rarity of the types which it consists, may be compared and it may even compete with the well-known fossiliferous sites.

\section{MATERIAL AND METHODS}

The macrofloristic material is almost entirely represented by foliar impressions and in a small amount of compressions, especially represented by pinophytes. For the moment, the few angiosperm compressions haven't allowed us to collect some cuticle that may be prepared.

The applied method was represented by obtaining some drawings done with the pin on transparent nylon pellicle under the stereomicroscope and copying them on calc papers, a proceeding which allows the observation of all the morphological details.

Sometimes, because of the obvious contrast between the color of the foliar impressions and the color of the host rock, there were used pictures as well for the comparisons and presentation.

\footnotetext{
${ }^{1}$ The Iron Gates Region Museum, Independenței no. 2, Drobeta Turnu Severin, Romania
} 


\section{FLORINA DIACONU}

\section{SYSTEMATIC PART}

\section{Phyllum PINATAE \\ Family PINACEAE}

Pinus sp.- binae (PI. I, fig. 1)

Material: samples BT - 187

Description: The impressions of some twin linear laminas, all fragmented, with the sizes: $\mathrm{L}=43 \mathrm{~mm}$; I=1 $\mathrm{mm}$.

Observations: Our sample is similar with those described and figured by Givulescu (1990, p. 35, PI.1, fig. 3).

The recent correspondent: By Givulescu (1990), it isn't sure to which present or fossil species these types of remains belong to, so that he gives them the artificial name of "binae" Beissner.

\section{Phyllum MAGNOLIOPHYTA \\ Class MAGNOLIATAE \\ Family MAGNOLIACEAE}

Magnolia sp. aff. M. acuminata Linné (PI. I, fig. 2)

Material: sample BT - 201

Description: The impression of a narrow obovate leaf, with an acute apex, the normal acute basis with the whole margin. The pinnate camptodromous-eucamptodromous venation, the obvious sinuous primary vein, gets thinner to the apex, the secondary veins alternatively disposed and the tertiary veins are fine and difficult to be seen. Observations: The sample is similar with the one described and figured by Givulescu (1990, p. 38, Pl. 7, fig. 5).

Occurrence: The species is signalized for the first time in the flora from Chiuzbaia. The recent correspondent: Magnolia acuminata a tree with a height up to $30 \mathrm{~m}$, large spread in Eastern USA. It grows in the Alleghany Mountains, in the mixt mesophyte forest, appearing on the slopes of the valleys in association with Castanea dentate, Acer rubrum, Fagus grandifolia, Quercus borealis and Liriodendron tulipifera. In the Cumberland Mountains it appears in a dominant association with Fagus or Tsuga, but with a $5 \%$ frequency. In the Quachita Mountains it appears in association with Quercus, Carya and Asimina triloba, Cercis canadensis. In the ever green forest from South -East, in the facies of the forest with Fagus - Magnolia in association with Quercus, Carya, Juglans, Ulmus americana, together with llex opaca, Carpinus caroliniana, Ostrya virginiana, too.

\section{Family LAURACEAE}

Sassafras subtriloba (Konno) Tanai et Onoe (PI. I, fig. 3)

Material: samples BT - 154, 155

Description: The impression and the contraimpression of a leaf (1/2 fragment) ovate, the apex and the basis haven't been preserved. The actinodromous imperfect marginal venation, with the primary weak sinuous vein, very thick on the basis, it gets thinner to the apex. The sideway primary veins are thick and give birth on their lower face to a number of secondary veins irregularly disposed, in an arch, which is anastomozed at the margin of the leaf. The tertiary nervation is horizontally disposed to the basis, which is between the secondary and the sideway veins. 
Observations: Although our sample is half from a lamina, it still looks like the one described and figured by Givulescu (1990, p. 40, PI. 16, fig. 2).

Occurrence: The types of Sassafras subtriloba were figured by Tanai and Onoe from the Japanese's Miocene and Pliocene.

The recent correspondent: Sassafras tzumu Hemsl from China and S. sassafras Krarst from east USA. S. tzumu Hemsl is a tall tree, of over $25 \mathrm{~m}$, with a wide spreading in China.

\section{Family BETULACEAE}

Ostrya sp. aff. O. virginiana (Miller) C. Koch (PI. II, fig. 1, 2)

Material: samples BT - 195, 196

Description: The impression of an ovate leaf, with the acute apex, without a basis, the serrated margin, weakly preserved. The pinnate simple craspedodromous venation, with basic vein slightly sinuous, a little thin towards the apex, and the secondary veins, slightly curved, have emergency angles that go down from the basis to the tip.

Observations: Because of the similarity with the leaves of Carpinus, the Ostrya ones are rarely signalized in the paleobotanical literature.

Occurrence: It was signalized only O. kryshtofovicii Baik. from Krinki in Sarmatian and $O$. antique Grub. from Asutas in Oligocene.

The recent correspondent: $O$. virginiana, a tree with a small height of 7-15 m, lives in USA, in the deciduous forest as a bush, in the arid and dusky regions.

\section{Family FAGACEAE}

Castanea gigas (Goepp.) lljinsk. (PI. III, fig. 2)

Material: one sample BT - 83

Description: Lanceolated leaf, of large dimensions, about L=200 mm, I= $72 \mathrm{~mm}$. The base and the apex cannot be seen, the margin is cut into teeth, with an oblique axis of the teeth, with an acute angle of the tooth, with a concave and prolonged apical margin of the teeth. The sinus is rounded and a little deepened, with a regular disposal of the teeth. The venation has a pinnate type simple craspedodromous, with secondary veins regularly disposed, with an emergency angle narrowed from the base to the tip. The tertiary venation is very regularly disposed, constantly oblique. Observations: Depending on the typical element of determination, the margin, looks like the sample, described by Givulescu (1991).

Quercus cf. muehlenbergii Engelmann (PI. III, fig. 3)

Material: one sample BT - 131

Description: The impression of lanceolate leaf, without an apex, with a cuneate basis, the side is strongly lobated, with the deepen sinus, a little rounded off, 10-11 triangular sharpen lobs, oriented up, ended in a short mucrone. The pinnate craspedodromous venation with the obvious main vein, thick at the basis, it is thinner towards the apex, and the secondary, parallel, straight veins are ended in lobs.

Observations: Our sample looks like the one described and figured by Givulescu (1970, p. 115-116, PI. V, fig. 1, 2).

The recent correspondent: By Givulescu (1970), this taxon is very similar to the present shape Q. muehlenbergii Engelm., it is a tree that lives in the e the NorthEast USA, with a wide frequency in the Basin of the Mississippi river and the Alleghany Mountains. 


\section{FLORINA DIACONU}

\section{Family JUGLANDACEAE}

Juglans acuminata Al. Braun (PI. II, fig. 3)

Material: one sample BT - 80

Description: An asymmetric ovate leaf, with the basis weakly asymmetric cordated, with the whole margin, slightly undulated, having few rare little teeth. The captodromouseucaptodromous venation, with the primary curved strong vein, the suboposite secondary, irregularly distanced and disposed veins, and their trajectory is curved and parallel.

Observations: Even if our sample is only half from a leaflet, it can still be compared with the one described and illustrated by Givulescu (1990: p. 102, Pl. 29, fig. 7).

Occurrence: Species frequently found in Mio-Pliocene from Europe.

The recent correspondent: Juglans regia, a tree of over $25 \mathrm{~m}$, that vegetates in the South-east of Europe, Balkan Peninsula, Minor Asia, the south of Caucaz, Persia, up to China at 1500-2400 m, where it is a component of the deciduous forests. In Europe vegetates from plain up to the middle mountainous area, in river meadow or in oak, elm, maple or lime forests.

\section{Family ACERACEAE}

Acer tricuspidatum Bronn (PI. II, fig. 5)

Material: one sample BT - 31

Description: The impression of trefoil leaf, with the lobes' margins double serrated, with teethes of different dimensions. The actinodromous basal perfect marginal venation, with the primary obviously vein, from which it sets out a pair of secondary veins, which finishes in the big teethes from margin.

Observations: The general aspect of the leaf and the nervation represent enough characters for a specifically ascription, but the absent oneself of a completely exemplary determines uncertainty.

Occurrence: This taxon is very frequently in Pliocene deposits from Romania.

The recent correspondent: Acer rubrum L., a hygrophyte tree of the 1st stature, very spread in the Eastern part of USA, between Labrador Peninsula and Big Lakes' Area, at North and, Mississippi Delta and Florida Peninsula, at South. A. rubrum L. preferred a humid soil and it lives in permanently flooding swamps' areas.

Acer cf. campestre L. (PI. III, fig. 1)

Material: one sample BT - 86

Description: A palmate deficient leaf, with cordate basis, and with a margin that can not be observed. The actinodromous basal perfect marginal venation, with the primary obviously straight vein which it gets thinner to the apex; the barrel sinuous lateral main vein creates on the extern margin secondary veins. The tertiary nervation is orthogonal reticulate type.

Observations: In Chiuzbaia collection it also exists the samaras of this taxon (Givulescu, 1990).

Occurrence: The spread of this taxon in Europe is large, but at Chiuzbaia it is new for the Neogen flora of Romania (Givulescu, 1990:128).

The recent correspondent: The taxon is very similar with Acer campestre L., which is a tree of 15-25 m height (exception: it can be a bush as well). The geographic area is from Europe to Caucaz, and it is a shadow and a semishadow temperament. Association: Carpinus, Quercus, or Fagus forests. 


\section{Family RHAMNACEAE}

Berchemia multinervis (Al. Br.) Heer (PI. II, fig. 4)

Material: one sample BT - 21

Description: A leaf with a suborbiculate shape, rounded tip, very weak emarginated, asymmetric subrotunded basis. The petiole has a $9 \mathrm{~mm}$ length. Camptodromous pinnate venation, the primary vein is curved and it gets thinner to the tip, the secondary veins are thin, alternly disposed with emergency angles that go down from the basis to the tip, with the subparallel trajectory and a slightly arched up to the margin of the limb where are strongly arched. The characteristic tertiary nervation is disposed oblique growing from the basis to the tip.

Observations: Description and iconography correspond to the one described and figured by Givulescu (1990: p. 134, Pl. 4, fig. 10).

Occurrence: It has a narrow spreading in the European Mio-Pliocene; in Romania it is known in Cornitel (Givulescu, 1957) and in the Jiu Valley (Givulescu, 1983).

The recent correspondent: Berchemia volubilis D. C. $=$ B. scadens (Hill.) C. Koch, a big shrub which vegetates in the southern Atlantic states of the USA: Virgina, Missouri, Florida and Texas.

PALEOCLIMATICAL AND PALEOPHYTOCENOTICAL CONSIDERATIONS In the previous researches (Petrescu et al., 2002; Țicleanu et al., 2002; Diaconu, 2002) there have been determined 25 taxa, to whom are added (Diaconu - in study) other 10 taxa, so that the floristic epitome of the Early Pontian deposits from Batoți is consisted of 35 taxa.

With this paper, the floristic epitome is filled with other 10 taxa: Pinus sp. binae, Magnolia sp. aff. M. acuminata Linné, Sassafras subtriloba (Konno) Tanai et Onoe, Ostrya sp. aff. O. virginiana (Miller) C. Koch, Castanea gigas (Goepp.) Iljinsk., Quercus cf. meuhlenbergii Engelmann, Juglans acuminata Al. Braun, Acer tricuspidatum Bronn, A. cf. campestre L. and Berchemia multinervis (Al. Br.) Heer. The present stage of knowledge of the Pontian flora from Batoți contains 45 taxa. Through the listed taxa the degree of confidence of the paleoecologycal and paleophytocenotical rendering grows.

The analysis of the whole paleofloristic summary shows the following phytogeografical composition regarding the number of elements: 19 - North Atlantic American, 6- East Asian, 3- Caucazian, 5- Central European, 2- North Pacific American, 2- Asia Minor, 5 - South European, 2- cosmopolitan and 2 - without any successor, and for the other 6 it hasn't been established a present correspondent.

The high dominance of the North-American elements, followed by the East Asian represents a phytogeographical characteristic of the Upper Miocene flora from Romania. In this respect, even if the flora from Batoți represents only $24 \%$ from the number of the floristic Upper Pontian species from Chiuzbaia (v. Givulescu, 1990), for the moment. Proportionally the two floras have the same characteristic: the prevalence of the North Atlantic American elements, and secondly the East Asian elements.

Besides this similar phytogeographycal composition we observe the fact that from the 45 taxa of flora from Batoti, 31 taxa are found in the flora from Chiuzbaia, too, representing more than half of the taxa determined by now. More 


\section{FLORINA DIACONU}

than this, the predominant elements from Chiuzbaia, Fagus silesiaca and different species of Quercus with the lobated leaf are the obvious dominant elements of the flora from Batoți, which makes a more interesting comparative analysis of the two floras.

Through its stratigraphic position, the flora from Batoți represents the only Early Pontian flora known up to now in our country. The 45 identified taxa to whom are added other taxa in study and many others that are still remained inside the deposits, because the research of the outcrop is still at the beginning, determine a very important paleoflora.

From the palinological point of view (v. Petrescu et al., 2002) in Romania and in its bordering countries it isn't known such a rich and varied microflora; so that, it may be said that through its importance, the succession of the Early Pontian deposits with fossil plants from Batoți must be included in the paleontological preserved sites.

\section{REFERENCES}

Diaconu F., 2002, Date noi privind studiul florei ponțiene de la Batoți (județul Mehedinți). Oltenia. Studii şi comunicări. Ştiințele naturii, vol. XVIII, p. 37-44, Craiova.

Diaconu F., 2004, New floristic elements in the Pontian deposits from Batoți (Mehedinti District). St. şi cerc., Geol. Geogr, 9, p. , Bistrița (in press).

Diaconu F., Țicleanu N., Petrescu I., Barbu V., Meilescu C. 2003, The importance of microand macroflora from Batoti (Mehedinti district) in the frame of the paleofloristic heritage of Romania. Studia, Univ. Babeş-Bolyai, Geologia, XLVIII, p.45-50 Cluj-Napoca

Givulescu R., 1957, Flora pliocenă de la Cornițel. Ed. Acad. R.S.R., p. 113, Bucureşti.

Givulescu R., 1970, O nouă contribuție la cunoaşterea florei din Pliocenul superior de la Chiuzbaia (Maramureş). D. S. ale şed. Vol. LV (1967 - 1968), p. 111-121, 5 pl., Bucureşti.

Givulescu R., 1983, Sur les classes foliaires de Raunkiaer et les limites de l'utilisation de cette méthodologie dans la paléphytologie. Studii şi comun. Muz. Brukental 25, p. 47-52, Sibiu.

Givulescu R., 1990, Flora fosilă a Miocenului Superior de Chiuzbaia. Ed. Acad. Române, Bucureşti.

Givulescu R., 1991, Plante fosile din forajul nr. 3153 de la Borod, județul Bihor. St. Cerc. GEOLOGIE, t. 36, p. $73-76$, Bucureşti.

Petrescu I., Bican-Brişan N., Meilescu C., Pătruțoiu I., 2002 ,The palynology of the Pontian from Batoți- Mehedinti (South - Western Romania). Acta Paleontol. III, Cluj-Napoca.

Ticleanu N., Petrescu I., Diaconu F., Meilescu C., Pătruțoiu I. 2002, Fossil plants from Pontian deposits at Batoți - Mehedinți. Studia, Univ. Babeş-Bolyai, Geologia, Special ISSUE, 1, p. 351-364, Cluj-Napoca. 
NEW CONTRIBUTION IN THE STUDY OF THE PONTIAN FLORA FROM BATOȚI (MEHEDINȚI COUNTY)

\section{PLATES CAPTIONS}

\section{Plate I:}

Fig. 1 - Pinus sp. binae;

Fig. 2 - Magnolia sp. aff. M. acuminata Linné $(x 1,5)$;

Fig. 3 - Sassafras subtriloba (Konno) Tanai et Onoe (x 1,5).

Plate II:

Figs. 1, 2 - Ostrya sp. aff. O. virginiana (Miller) C. Koch (x 1,5) - impression and contraimpresion;

Fig. 3 - Juglans acuminata Al. Braun (x 1, 5);

Fig. 4 - Berchemia multinervis (Al. Br.) Heer $(x 1,5)$;

Fig. 5 - Acer tricuspidatum Bronn.

Plate III:

Fig. 1 - Acer cf. campestre L.;

Fig. 2 - Castanea gigas (Goepp.) lljinsk.;

Fig. 3 - Quercus cf. meuhlenbergii Engelmann. 


\section{FLORINA DIACONU}

Plate I
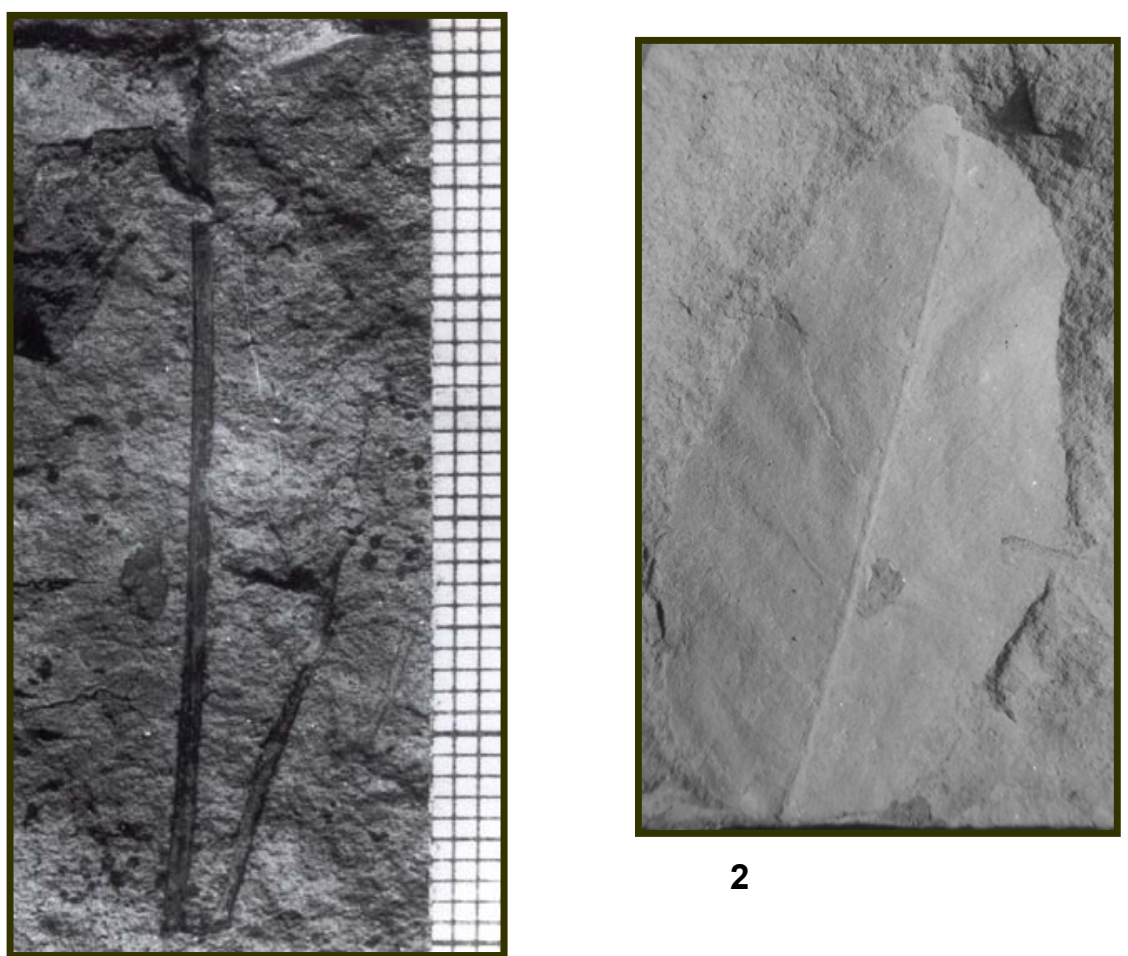

2

1

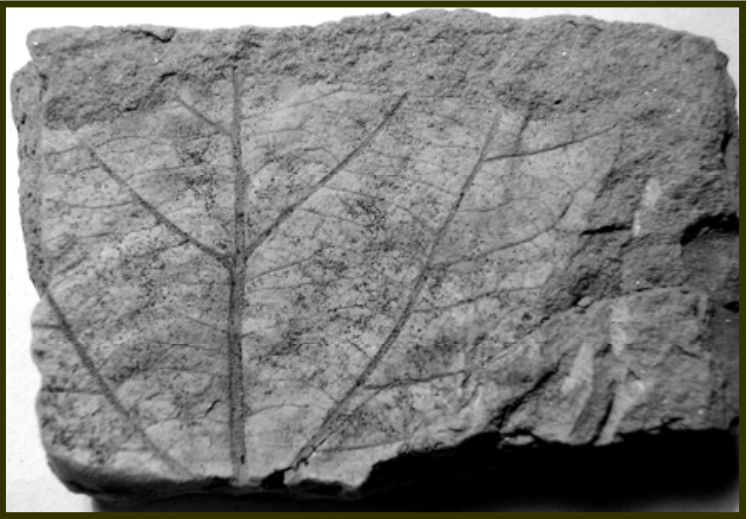

3 


\section{Plate II}
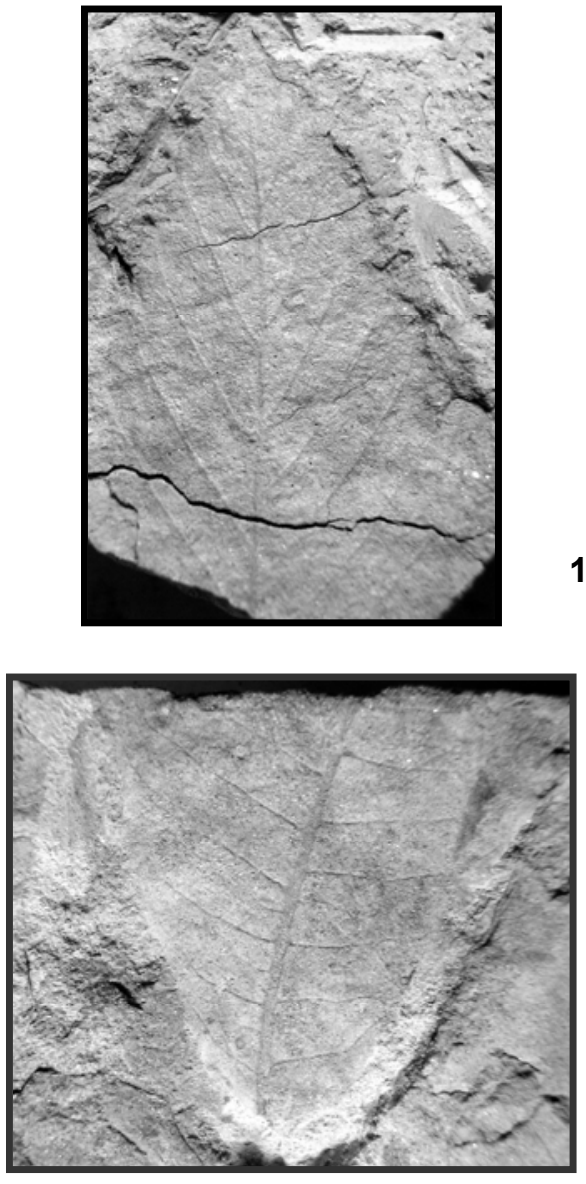

3

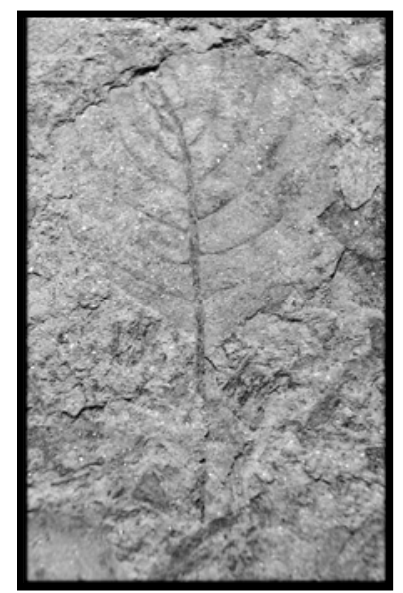

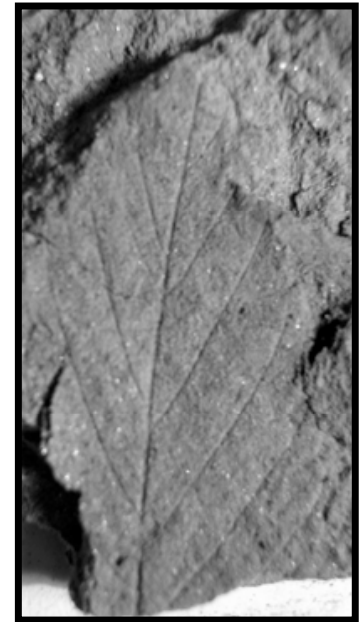

2

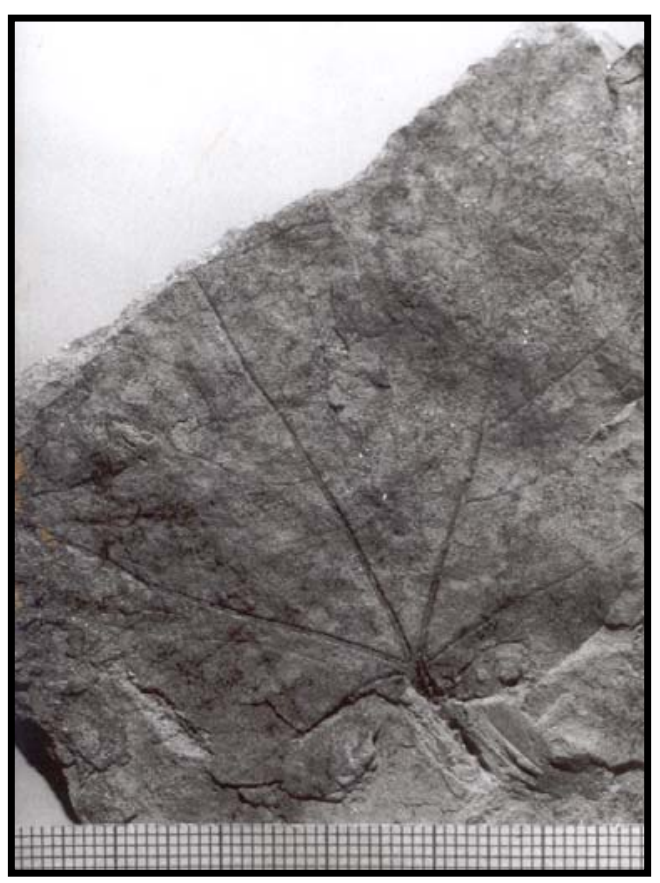

5 
FLORINA DIACONU

Plate III



